\title{
68. Studies on the Acetone-Butyl Alcohol Fermentation
}

\section{Intermediates in the Fermentation of Glucose by $\mathbf{C l}$. acetobutylicum \\ 3. Potassium as an Essential Factor in the Fermentation of Maize Meal by $\mathrm{Cl}$. acetobutylicum (BY)}

\author{
By Ronald Davies, From the Biochemical Laboratory, Cambridge \\ (Received 3 July 1942)

\section{INTERMEDIATES IN THE FERMENTATION OF GLUCOSE BY $C L . A C E T O B U T Y L I C U M$}

The technique of preparing active cell suspensions of $\mathrm{Cl}$. acetobutylicum (Weizmann) capable of giving normal fermentation products from glucose has been described [Davies \& Stephenson, 1941]. It was stated that these suspensions rapidly lost their activity. In the present paper further experiments on the decay of activity are described and also various experiments on reactions performed by suspensions of the organism, in particular experiments relating to the reduction of butyric acid to butyl alcohol and to the formation of acetone.

\section{Methods and technique}

The analytical methods and the technique of growing the organism and preparing cell suspensions were the same as previously described [Davies \& Stephenson, 1941] unless otherwise stated.

Estimation of acetone and acetoacetic acid in a mixture. To determine the acetone the sample was brought to $p \mathrm{H} 7.5$ and the acetone distilled for $10 \mathrm{~min}$. in vacuo into $25 \mathrm{ml}$. $N / 100 \mathrm{I}_{2}+5 \mathrm{ml}$. $N \mathrm{NaOH}$ in the apparatus used for the estimation of acetone. Under these conditions acetoacetic acid does not distil. Acetone + acetoacetic acid was estimated by strongly acidifying the sample and distilling off the acetone by boiling at atmospheric pressure. The acetoacetic acid was obtained by difference.

The organism. Two strains of $\mathrm{Cl}$. acetobutylicum have been used, the Weizmann strain and the BY strain; the particular strain used in a given experiment is indicated in each instance.

\section{Experiments on the decay of activity of suspensions}

Rate of decay. A suspension of cells was prepared and was kept in a test-tube in air at room temperature. After given intervals of time its activity was determined by measuring the rate of $\mathrm{H}_{2}$ production from both glucose and pyruvate in Warburg manometers. The

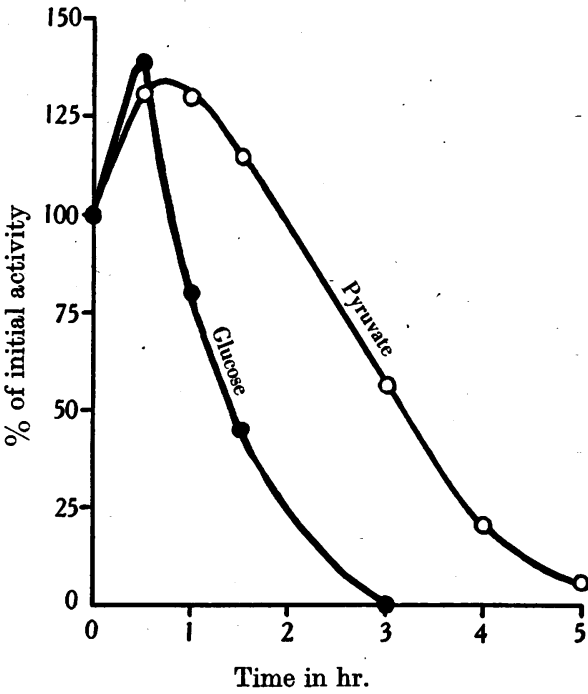

Fig. 1. Effect of time on activity of cell suspensions. Organism: Weizmann strain.

results are shown in Fig. 1 where the activity expressed as a percentage of the initial activity is plotted against time. The suspension had lost all activity towards glucose 
after $3 \mathrm{hr}$. and $96 \%$ of its activity towards pyruvate after $5 \mathrm{hr}$. The activity peaks shown in Fig. 1 were not observed in every experiment.

\section{Table 1. Effect of various substances and conditions on rate of decay}

In all cases activities were determined manometrically by measuring the $Q_{\mathbf{H}_{2}}$ over the first 5 min. Warburg manometers were used containing $0.6 \mathrm{ml}$. $M / 2$ acetate buffer $p \mathrm{H} 5 \cdot 0,0 \cdot 1 \mathrm{ml}$. cell suspension (20-30 mg. dry wt./ml. except in (h)), $1.8 \mathrm{ml}$. water and, in the side bulb, $0 \cdot 3 \mathrm{ml}$. $M / 10$ glucose. Gas phase $\mathrm{H}_{2} ;$ temp. $37^{\circ}$.

In $(a)$ and $(b), 10 \mathrm{ml}$. cell suspension contained in each of four modified Thunberg tubes were gassed with the requisite gas for $\frac{1}{2} \mathrm{~min}$. and kept in an atmosphere of that gas; samples were expelled at intervals by forcing the corresponding gas into the tube.

In $(c)$ and $(d), 7 \mathrm{ml}$. cell suspension containing $1 \mathrm{mg} . / \mathrm{ml}$. of one of the substances named were kept in air in a test-tube at room temp.

In $(e),(f)$ and $(g), 10 \mathrm{ml}$. cell suspension containing glucose or galactose to the final concentrations given were kept in air in a test-tube at room temp. or at $0^{\circ}$.

In $(h), 10 \mathrm{ml}$. cell suspension of the strengths given were kept in a test-tube in air at room temp.

The values of $Q_{\mathrm{H}_{2}}$ have been adjusted so that in each experiment the $Q_{\mathrm{H}_{2}}$ of the freshly. prepared suspension was 100 .

$$
p-\mathrm{AB}=p \text {-aminobenzoic acid. }
$$

Organism: Weizmann strain.

(b)

\begin{tabular}{crrrr}
$\begin{array}{c}\text { Age of } \\
\text { suspension }\end{array}$ & \multicolumn{4}{c}{$(a)$} \\
\cline { 2 - 5 } hr. & Air & \multicolumn{1}{c}{$\mathrm{O}_{2}$} & $\mathrm{~N}_{2}$ & $\mathrm{H}_{2}$ \\
0 & 100 & 100 & 100 & 100 \\
${ }_{3}^{\frac{3}{4}}$ & 16 & 0 & 31 & 32 \\
$1 \frac{1}{2}$ & 3 & 0 & 16 & 16 \\
$2 \frac{1}{4}$ & 0 & 0 & 5 & 5 \\
3 & 0 & 0 & 0 & 0
\end{tabular}

$\begin{array}{rrr} & \mathrm{H}_{2}+ & \\ \mathrm{Air} & \mathrm{CO}_{2} & \mathrm{CO}_{2} \\ 100 & 100 & 100 \\ 47 & 50 & 73 \\ 27 & 31 & 42 \\ 13 & 16 & 21 \\ 1 & 3 & 3\end{array}$

(d)

$\begin{array}{rc} & \\ \text { Air } & \text { Nicot- } \\ 100 & 100 \\ 46 & 49 \\ 22 & 25 \\ 0 & 3 \\ 0 & 0\end{array}$

\begin{tabular}{|c|}
\hline $\begin{array}{l}\text { Age of } \\
\text { suspension } \\
\mathrm{hr} .\end{array}$ \\
\hline 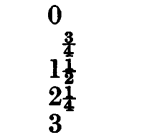 \\
\hline
\end{tabular}

$\begin{array}{crrcc}\begin{array}{c}\text { Age of } \\ \text { suspension } \\ \text { hr. }\end{array} & \text { Air } & \begin{array}{c}M / 100 \\ \text { Glucose }\end{array} & \begin{array}{c}M / 50 \\ \text { Glucose }\end{array} & \begin{array}{c}M / 25 \\ \text { Glucose }\end{array} \\ 0 & 100 & 100 & 100 & 100 \\ & 30 & 312 & 294 & 334 \\ 1 \frac{3}{\frac{3}{2}} & 6 & 320 & 394 & 448 \\ 2 \frac{1}{2} & 4 & 142 & 310 & 440 \\ 3 & 0 & 86 & 222 & 441\end{array}$

Age of suspension $\mathrm{hr}$.

$32 \cdot 5$
100
87
73
53
-

$20 \cdot 3$
100
75
48
-
-

$\begin{array}{rr}\text { mg. dry wt. } \\ 12 \cdot 2 & 6 \cdot 1 \\ 100 & 10 \\ 54 & 5 \\ 42 & 37 \\ - & 3\end{array}$

(h)

Adenylic
acid
100
33
20
5
0

\begin{tabular}{|c|c|c|c|}
\hline Air & $\begin{array}{l}\text { Cys- } \\
\text { teine }\end{array}$ & $\begin{array}{l}\text { Gluta- } \\
\text { thione }\end{array}$ & $p-\mathrm{AB}$ \\
\hline 100 & 100 & 100 & 100 \\
\hline 100 & 97 & 81 & 89 \\
\hline 47 & 57 & 50 & 58 \\
\hline 28 & 34 & 17 & 30 \\
\hline 17 & 14 & 13 & 12 \\
\hline
\end{tabular}

- (e)

$\begin{array}{rcc}\text { Air } & \begin{array}{c}M / 100 \\ \text { Glucose }\end{array} & \begin{array}{c}M / 100 \\ \text { Galactose }\end{array} \\ 100 & 100 & 100 \\ 23 & 177 & 23 \\ 6 & 104 & 6 \\ 0 & 66 & 0 \\ 0 & 39 & 0\end{array}$,

(g)

\begin{tabular}{|c|c|c|c|}
\hline $\begin{array}{l}\text { Air } \\
18^{\circ}\end{array}$ & $\underset{0^{\circ}}{\operatorname{Air}}$ & $\begin{array}{c}M / 100 \\
\text { Glucose } \\
18^{\circ}\end{array}$ & $\begin{array}{c}M / 100 \\
\text { Glucose } \\
0^{\circ}\end{array}$ \\
\hline 100 & 100 & 100 & 100 \\
\hline 121 & 36 & 340 & 52 \\
\hline 48 & 14 & 346 & 23 \\
\hline 19 & 4 & 194 & 15 \\
\hline 8 & 0 & 4 & 11 \\
\hline
\end{tabular}

(h) 8 (1)

Effect of anaerobiosis, temperature etc. on the rate of decay. The effect of storing the suspension in air, $\mathrm{O}_{2}, \mathrm{~N}_{2}, \mathrm{H}_{2}, \mathrm{CO}_{2}$ and $\mathrm{H}_{2}+\mathrm{CO}_{2}$ and the effect of storage temperature and of various compounds on the rate of decay has been studied. Experimental details and the results are given in Table 1. Mann \& Quastel [1941] have shown that the destruction 
of cozymase in brain tissue can be inhibited by the addition of nicotinamide to the tissue. Assuming that cozymase destruction might be responsible for the decay in activity of $\mathrm{Cl}$. acetobutylicum suspensions the effect of nicotinamide was tried; it did not prevent decay, neither did adenosine nor the two together. Reducing agents such as cysteine and reduced glutathione were likewise ineffective. In fact the activity was maintained only when the cells were fermenting glucose. At $0^{\circ}$, where fermentation does not take place, even glucose was ineffective. The figures in Table $1(f)$ show quite clearly that as the glucose was used up the protective action on the activity disappeared. At a concentration of $M / 100$ the glucose had disappeared after $1 \frac{1}{2} \mathrm{hr}$., at $M / 50$ after $2 \frac{1}{4} \mathrm{hr}$. This was shown by the fact that there was no evolution of gas in the manometers during the second 5 min. of the equilibration period. At a concentration of $M / 25$ the glucose had not disappeared after $3 \frac{3}{4} \mathbf{h r}$.

Effect of cozymase. It was still considered possible that cozymase destruction was involved in the decay and to settle this point the cozymase in the cells was determined before and after a period of incubation at $37^{\circ}$, using the lactic dehydrogenase-diaphorasemethylene blue system. The results are given in Table 2 . It is seen that cozymase was not

\section{Table 2. Stability of cozymase in cell suspensions}

Cell suspensions were prepared containing $0,0.08$ and $0.4 \mathrm{mg}$. added cozymase per ml. and $28 \cdot 6 \mathrm{mg}$. cells per $\mathrm{ml}$. The suspensions also contained $M / 50$ acetate buffer $p H \mathbf{H} \cdot 0$. A portion of each suspension was immediately boiled and tested for cozymase in Thunberg tubes. The remainder of the suspension was incubated for $3 \mathrm{hr}$. at $37^{\circ}$ and again tested for cozymase. The medium from which the cells had been harvested was passed through a Seitz filter and the filtrate also tested for cozymase.

The Thunberg tubes contained $1 \mathrm{ml}$. lactic dehydrogenase [Green, Needham \& Dewan, 1937 ], $1 \mathrm{ml}$.

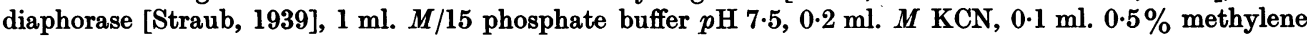
blue, $0.5 \mathrm{ml}$. cell suspension or other source of cozymase, and in the hollow stopper $0.1 \mathrm{ml} .2 \mathrm{M}$ sodium lactate.

The fermentative activity of the cell suspension towards glucose was determined manometrically before and after incubation.

Cell suspension

Cell suspension $+0.08 \mathrm{mg}$. $\mathrm{CoI} / \mathrm{ml}$.

Cell suspension + 0.4 mg. $\mathrm{CoI} / \mathrm{ml}$.

Seitz filtrate

$0.08 \mathrm{mg}$. CoI $/ \mathrm{ml}$.

$0.4 \mathrm{mg} . \mathrm{CoI} / \mathrm{ml}$.

No cozymase
Organism: Weizmann strain.

Initial
reduction time
$10 \mathrm{~min} .10 \mathrm{sec}$.
$6 \mathrm{~min} .50 \mathrm{sec}$
$3 \mathrm{~min} .35 \mathrm{sec}$.
$2 \mathrm{hr}$.
$7 \mathrm{~min} .30 \mathrm{sec}$
$2 \mathrm{~min} .50 \mathrm{sec}$
$2 \mathrm{hr} .10 \mathrm{~min}$.

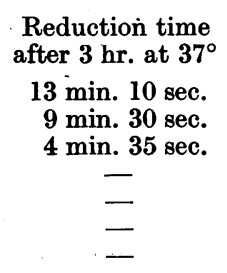

$\begin{array}{cc}\text { Initial } & \text { Final } \\ Q_{\mathrm{H}_{2}} & Q_{\mathrm{H}_{2}} \\ 112 & 0 \\ 112 & 0 \\ 112 & 0 \\ - & - \\ - & - \\ - & -\end{array}$

destroyed to any appreciable extent during a period in which the glucose-fermenting activity fell to zero. The decay in activity therefore cannot be ascribed to destruction of cozymase; its cause remains to be found.

It is obviously impracticable in most experiments to use glucose as a stabilizing agent for the activity, and if reproducible results are to be obtained in the absence of glucose it is necessary so to arrange the experiment that the suspension is used within $15 \mathrm{~min}$. of harvesting the cells.

\section{Fermentation of possible intermediates}

The action of cell suspensions on some substances that have been suggested as intermediates in the acetone-butanol fermentation has been investigated. $0.1 \mathrm{ml}$. portions of $M / 10$ solutions of.these substances were incubated with cell suspensions in Warburg manometers in an atmosphere of $\mathrm{H}_{2}$ at $p \mathrm{H} \mathrm{5.0}$ (and in the case of butyric acid $p H 4.0$ ) and the liberation of $\mathrm{H}_{2}$ and $\mathrm{CO}_{2}$ or the uptake of $\mathrm{H}_{2}$ was measured. Both strains of organism were used. The substances examined were: glyceraldehyde, phosphoglyceric acid, hexosediphosphate, lactic acid, formic acid, methylglyoxal, acetoacetic acid, oxaloacetic 
acid, fumaric acid, butyric acid, $\alpha$-hydroxybutyric acid, $\beta$-hydroxybutyric acid, 2:3dihydroxybutyric acid, glyoxylic acid, tetronic acid, crotonic acid, trans- $\gamma$-hydroxycrotonic acid, tetrolic acid and vinylacetic acid. Except for acetoacetic and oxaloacetic acids there was no evolution or uptake of gas in any instance although glucose and pyruvate were vigorously fermented. Therefore, with the two exceptions stated, these substances cannot be attacked by cell suspensions of $C l$. acetobutylicum in the presence of $\mathrm{H}_{2}$ only.

Reduction of unsaturated 4-C acids by cells actively fermenting glucose. The last four unsaturated acids in the list and fumaric acid were incubated with cell suspensions in the presence of glucose to see if they could be utilized when glucose was being fermented. $0 \cdot 1 \mathrm{ml}$. portions of $M / 10$ solutions of these compounds were incubated with $0 \cdot 1 \mathrm{ml} . M / 10$ glucose, $1.3 \mathrm{ml} . M / 5$ acetate buffer $p H 5.0$ and $0.5 \mathrm{ml}$. cell suspension $(30 \mathrm{mg}$. dry wt. cells $/ \mathrm{ml}$.) in an atmosphere of $\mathrm{H}_{2}$ until fermentation of the glucose had ceased. The experiment was carried out in Warburg manometers and the $\mathrm{H}_{2}$ evolved was measured and compared with that evolved from glucose alone. The residual unsaturated acid was then determined by measuring the $\mathrm{H}_{2}$ taken up when a suitable aliquot was catalytically hydrogenated by means of palladium-charcoal. For this purpose Warburg manometers were used containing $0.5 \mathrm{ml} .5 \mathrm{~N}_{2} \mathrm{SO}_{4}, 0.2 \mathrm{ml}$. palladium-charcoal suspension and $1.3 \mathrm{ml}$. water in the main compartment and $1.0 \mathrm{ml}$. fermentation fluid in the side bulb; the manometers were filled with $\mathrm{H}_{2}$ (freed from traces of $\mathrm{O}_{2}$ by passage over reduced copper heated in a furnace) and equilibrated for $15 \mathrm{~min}$. at $37^{\circ}$. The contents of the side bulb were then mixed with the catalyst and the $\mathrm{H}_{2}$ uptake measured. The presence of the cells slows down the hydrogenation somewhat but does not affect the amount of $\mathrm{H}_{2}$ taken up and it was not found necessary to remove them [cf: W. A. Johnson, 1939]. Control hydrogenations on the cell suspension alone and on the completely fermented glucose were always carried out but were always negative.

The results (Table 3) show that with the possible exception of fumaric acid none of the compounds is utilized and therefore they do not function as intermediates in the fermentation of glucose.

\section{Table 3. Reduction of unsaturated 4-C acids in presence of glucose}

\begin{tabular}{|c|c|c|c|}
\hline Șubstrate & $\begin{array}{c}\mathrm{H}_{2} \text { from glucose } \\
\text { and 4-C acid } \\
\mu \mathrm{l} .\end{array}$ & $\begin{array}{c}\text { Initial } \\
\text { 4-C acid } \\
\mu l .\end{array}$ & $\underset{\mu \mathrm{A}-\mathrm{C} \text { acid }}{\mathrm{Fl} .}$ \\
\hline Glucose & 496 & - & - \\
\hline Glucose and vinylacetic acid & 492 & 206 & 180 \\
\hline Glucose and crotonic acid & 505 & 224 & 208 \\
\hline Glucose and-trans- $\gamma$-hydroxycrotonic acid & 500 & 224 & 222 \\
\hline Glucose and tetrolic acid & 511 & 224 & 209 \\
\hline Glucose and fumaric acid & 484 & 224 & 142 \\
\hline
\end{tabular}

Organism: BY strain.

Oxaloacetic acid is rapidly attacked, the optimum $p \mathrm{H}$ for its decomposition being $4 \cdot 0$. The products of decomposition have not been determined but presumably it is first decarboxylated to pyruvic acid which is then broken down in the usual way.

The fact that formic acid is not attacked disposes of the theory that $\mathrm{H}_{2}$ and $\mathrm{CO}_{2}$ are produced from formic acid under the influence of formic hydrogenlyase. $\mathrm{Cl}$. acetobutylicum is therefore similar to $\mathrm{Cl}$. tetanomorphum and $\mathrm{Cl}$. welchii in producing $\mathrm{H}_{2}$ from glucose but not from formate [Woods \& Clifton, 1937; Woods, unpublished].

Thunberg tube experiments using the methylene blue technique have shown that $C l$. acetobutylicum possesses enzymes which can activate glucose, pyruvate and lactate as $\mathrm{H}_{2}$ donators, but that the dehydrogenases for succinic and formic acids and for alcohol are absent (Table 4). An extremely active hydrogenase is present however, the most active suspension encountered having $Q_{\text {methylene blue; hydrogen }}=12,000$. 
Table 4. Dehydrogenase activity of Cl. acetobutylicum suspensions

Thunberg tubes contained $1 \mathrm{ml}$. cell suspension $(4 \cdot 2 \mathrm{mg} . / \mathrm{ml}$.), $1 \mathrm{ml}$. $M / 15$ phosphate buffer $p H 5 \cdot 5$, 1.ml. $M / 10$ substrate, and in the stopper $0.5 \mathrm{ml} .0 \cdot 1 \%$ methylene blue.

$\begin{array}{lccc}\text { Substrate } & Q_{\text {x.8. }} & \text { Substrate } & Q_{\text {к.8. }} \\ \text { Glucose } & 106 & \text { Formate } & 0 \\ \text { Pyruvate } & 34 & \text { Succinate } & 0 \\ \text { Lactate } & 10 & \text { Ethyl alcohol } & 0 \\ & \text { Organism }: \text { Weizmann strain. } & \end{array}$

Acetoacetic acid as an intermediate. Johnson, Peterson \& Fred [1933] have shown that acetoacetic acid is rapidly broken down to acetone both in culture and by washed suspensions of $C l$. acetobutylicum, the rate of attack being at a maximum when the rate of formation of acetone in the culture is also at a maximum. These findings have been confirmed by the manometric technique using Warburg manometers. $0 \cdot 2 \mathrm{ml} . M / 10$ acetoacetic acid wias shaken with $0.2 \mathrm{ml}$. cell suspension $(25 \mathrm{mg} . / \mathrm{ml}$.) in $2.6 \mathrm{ml} . M / 10$ acetate buffer $p \mathrm{H} \mathrm{5.0} \mathrm{in} \mathrm{an} \mathrm{atmosphere} \mathrm{of} \mathrm{H}_{2}$ and the $\mathrm{CO}_{2}$ evolved was measured. One manometer contained $0.2 \mathrm{ml} .20 \% \mathrm{NaOH}$ in the centre cup to show that the only gas evolved was $\mathrm{CO}_{2}$. When $\mathrm{CO}_{2}$ production had ceased the acetone and acetoacetic acid in the manometers were estimated as previously described; a control was done using boiled cells. The results are given in Table 5. It is clear that acetoacetic acid is enzymically decarboxylated quantitatively to acetone; the low yield of acetone may be accounted for by loss through vaporization while the manometers were shaking at $37^{\circ}$.

Table 5. Decarboxylation of acetoacetic acid

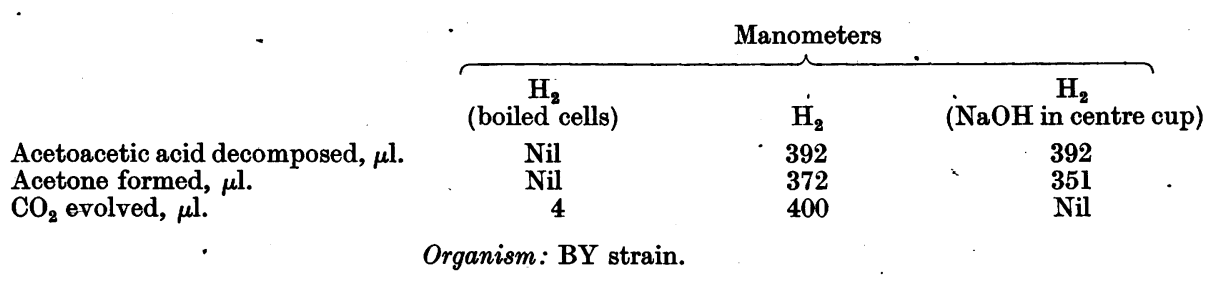

The optimum $p \mathrm{H}$ for acetoacetic acid decarboxylation was determined manometrically by measuring the rate of $\mathrm{CO}_{2}$ evolution over the first $5 \mathrm{~min}$. when cell suspensions were shaken with acetoacetic acid in acetate buffers. Fig. 2 shows that the optimum lies at about $p \mathrm{H} 4 \cdot 3$.

Fig. 3 shows the variation in acetoacetic decarboxylase activity of the cells with age of the culture. 21 . of $2 \%$ glucose-liver medium were sown with $40 \mathrm{ml}$. of a $5 \%$ maize meal culture and incubated at $37^{\circ}$ in an atmosphere of $\mathrm{H}_{2}$. Samples were withdrawn at intervals for the preparation of cell suspensions. The decarboxylase activity of the suspensions was measured as described above. Up to $8 \mathrm{hr}$. no acetone could be detected in the culture by Rothera's test; from 9 to $12 \mathrm{hr}$. there was a slight reaction increasing in intensity; at $13 \mathrm{hr}$. there was $0.1 \mathrm{mg}$. acetone $/ \mathrm{ml}$. culture and by $27 \mathrm{hr}$. this had risen to $0.5 \mathrm{mg} . / \mathrm{ml}$. The activity of the cell suspension from the $27 \mathrm{hr}$. sample was very high $\left(Q_{\mathrm{CO}_{2}}=596\right)$.

A few other properties of the acetoacetic acid decarboxylase are worth noting. (1) It will work aerobically just as. well as anaerobically, thus differing from all the other enzymes of this organism so far studied. (2) It stands up to acetone treatment and in an acetone powder of whole cells retains its activity almost undiminished for months. (3) The enzyme can be extracted from the acetone powder by water at $37^{\circ}$. 


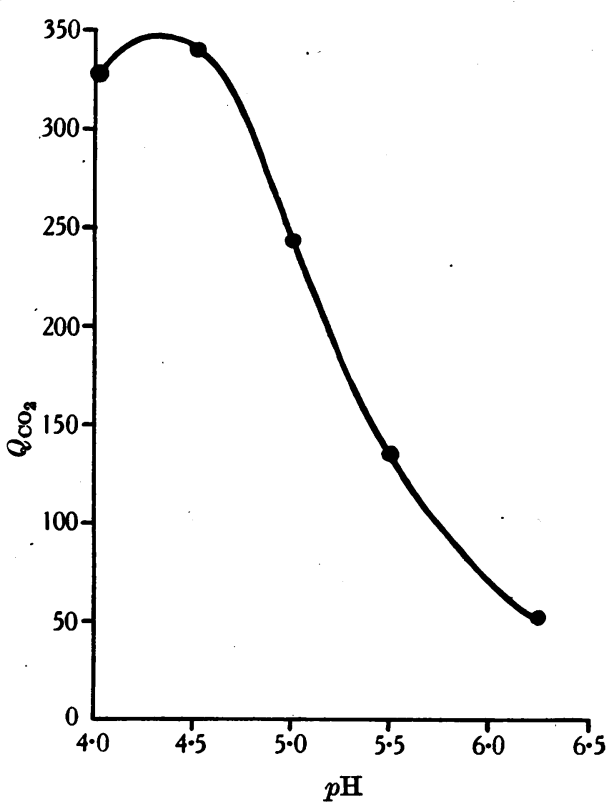

Fig. 2.

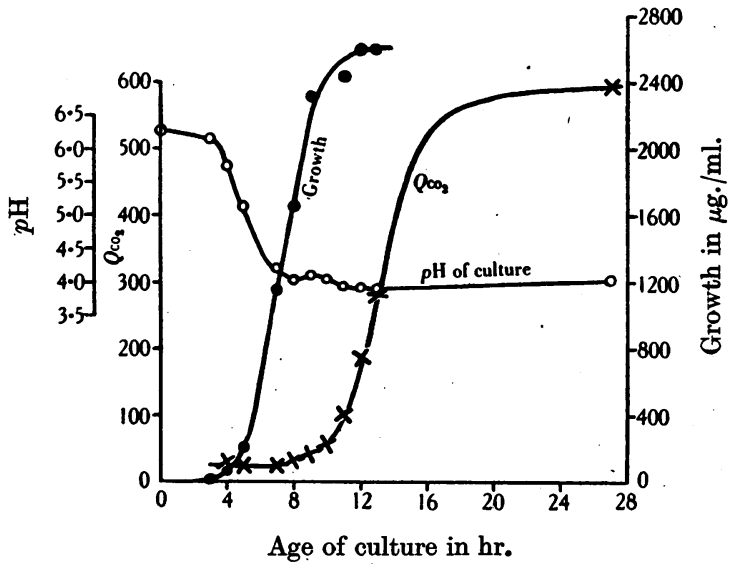

Fig. 3.

Fig. 2. Variation of acetoacetic acid decarboxylase activity with $p H$. The reactions were carried out in Warburg manometers containing $0.2 \mathrm{ml}$. cell suspension, $1.9 \mathrm{ml}$. water and $0.6 \mathrm{ml} . M / 2$ acetate buffer of the desired $p \mathrm{H}$ in the main compartment; the side bulb contained $0.3 \mathrm{ml} . M / 10$ acetoacetic acid (neutralized to $p H 7 \cdot 0$ ). Gas phase air; temp. $37 \cdot 5^{\circ}$. The $p H$ measurements were made by means of the glass electrode. Organism: BY strain.

Fig. 3. Variation of acetoacetic acid decarboxylase activity with age of culture. The $p H$ determinations were made by means of the glass electrode. Growth was estimated by means of a photoelectric turbidimeter. Organism: BY strain.

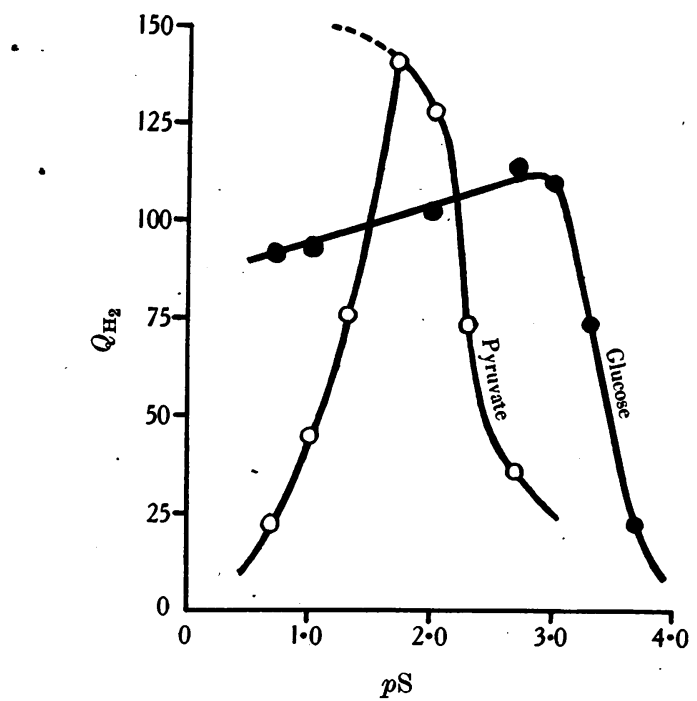

Fig. 4. Effect of substrate concentration on rate of fermentation. Organism: Weizmann strain. 


\section{Effect of substrate concentration on rate of fermentation}

Glucose. The effect of substrate concentration on the rate of $\mathrm{H}_{2}$ production from glucose was determined manometrically using Warburg manometers. Each manometer contained $0 \cdot 6 \mathrm{ml} . M / 2$ acetate buffer $p \mathrm{H} 5 \cdot 0,0 \cdot 3 \mathrm{ml}$. cell suspension $(10.8 \mathrm{mg} . / \mathrm{ml}$.$) ; in the$ side bulb sufficient $M, M / 10$ or $M / 100$ glucose to give final concentrations ranging from $M / 5$ down to $M / 5000$. The centre cup contained $0.2 \mathrm{ml} .20 \% \mathrm{NaOH}$ and the total volume of fluid was made up to $3.0 \mathrm{ml}$. with water; the manometers were filled with $\mathrm{H}_{2}$ and shaken at $37^{\circ}$. The results are given in Fig. 4. The enzyme system displays a high affinity for its substrate, the concentration of glucose necessary to saturate the system being about $M / 1000$; it may however be lower than this since, with final concentrations of glucose of $M / 2000$ and $M / 5000$, there is so little substrate present that the concentration may have been reduced below the saturation level before the zero reading could be taken after tipping the manometers.

Pyruvate. This was determined in the same way as for glucose, pyruvate at $p \mathrm{H} 5 \cdot 0$ being substituted for glucose. The affinity curve for pyruvate is included in Fig. 4 . It is seen that concentrations of pyruvic acid greater than $M / 50$ are inhibitory whilst at concentrations less than this the system is not saturated. The affinity of the pyruvate system for its substrate is seen to be much lower than that of the glucose system.

\section{Fermentation of other sugars}

In culture, $\mathrm{Cl}$. acetobutylicum will ferment a number of carbohydrates and it was of interest to ascertain whether cell suspensions would ferment sugars other than glucose. The organism was therefore grown on the usual liver medium but with $2 \%$ maltose or $2 \%$ sucrose in the place of glucose. The ability of cell suspensions prepared from these cultures to ferment glucose, fructose, maltose and sucrose was then investigated by the usual-manometric technique. The results (Table 6) give a good example of adaptive and

\section{Table 6. Fermentation of sugars by $\mathrm{Cl}$. acetobutylicum}

The manometers contained $0 \cdot 6 \mathrm{ml}$. $M / 2$ acetate $p H 5 \cdot 0,0 \cdot 3 \mathrm{ml}$. cell suspension $(20 \mathrm{mg}$. dry wt./ml.), $2.0 \mathrm{ml}$. water, and in the side bulb $0.1 \mathrm{ml}$. $M$ substrate. Gas phase $\mathrm{H}_{2} ;$ temp. $37^{\circ}$.

$\begin{array}{ccccc}\text { Substrate in } & \overbrace{\text { Glucose }} & \text { Fructose } & \text { Maltose } & \text { Sucrose } \\ \text { growth medium } & Q_{\mathrm{H}_{2}} & Q_{\mathrm{H}_{2}} & Q_{\mathrm{H}_{2}} & Q_{\mathrm{H}_{2}} \\ 2 \% \text { glucose } & 450 & 143 & 21 & 0 \\ 2 \% \text { maltose } & 454 & - & 298 & 37 \\ 2 \% \text { sucrose } & 307 & 286 & 254 & 262 \\ & \text { Organism } & \text { : Weizmann strain. } & \end{array}$

constitutive enzymes. It is interesting that growing the cells on sucrose enables the cell to ferment maltose although the reverse is not the case. The adaptive nature of the sucrose-fermenting enzymes is of importance in connexion with the industrial fermentation of molasses.

\section{Reduction of butyric acid to butyl alcohol}

Without hazarding any theory on the production of 4-C compounds from glucose and pyruvate the problem of the reduction of butyric acid to butyl alcohol has been studied. It has already been shown manometrically that butyric acid is not reduced by $\mathrm{H}_{2}$ in the presence of cell suspensions, and the fact that a considerable proportion of the glucose still remains to be fermented in a growth fermentation when the concentration of butyric acid starts to fall and butyl alcohol is rapidly being formed, suggested that the reducing agent might be glucose or some closely related substance. Experiments were therefore devised to show whether butyl alcohol could be formed from glucose and butyric and 
acetic acids only, or whether some unknown intermediate formed in the early stages of the fermentation was essential to the reduction of butyric acid.

$850 \mathrm{ml}$. of the usual medium containing $2 \%$ glucose were fermented until about half the glucose had disappeared. The culture was then divided into two parts with aseptic precautions, one half being allowed to ferment to completion. The other half was centrifuged so as to remove the cells and the medium was replaced by an equal quantity of fresh medium containing glucose, acetic and butyric acids in approximately the same concentrations as in the medium removed; the fermentation was then carried to completion, both cultures being analysed for the usual products. The result of one such experiment is given in Table 7. This shows that the cells from a half-fermented culture

\section{Table 7. Experiment on the reduction of butyric acid}

\begin{tabular}{|c|c|c|c|c|c|}
\hline & $\begin{array}{l}\text { Original culture } \\
\text { initially }\end{array}$ & $\begin{array}{l}\text { Same culture } \\
\text { at half } \\
\text { fermentation }\end{array}$ & $\begin{array}{c}\text { New medium } \\
\text { initially }\end{array}$ & $\begin{array}{l}\text { New medium } \\
\text { after complete } \\
\text { fermentation }\end{array}$ & $\begin{array}{l}\text { Original culture } \\
\text { after complete } \\
\text { fermentation }\end{array}$ \\
\hline Conc. $\mathrm{mg} . / \mathrm{ml}$. & $p \mathrm{H} \ldots \quad 6 \cdot 29$ & $4 \cdot 03$ & $4 \cdot 03$ & $4 \cdot 09$ & $4 \cdot 24$ \\
\hline Glucose & $21 \cdot 1$ & 11.9 & $10 \cdot 1$ & $0 \cdot 4$ & $1 \cdot 01$ \\
\hline Acetone & None & $0 \cdot 15$ & None & $0 \cdot 79$ & $1 \cdot 22$ \\
\hline Butyl alcohol & None & 0.43 & None & 4.08 & 4.53 \\
\hline Ethyl alcohol & None & None & None & None & $0 \cdot 30$ \\
\hline Butyric acid & None & $3 \cdot 04$ & $3 \cdot 36$ & 1.55 . & 0.69 \\
\hline Acetic acid & None & $0 \cdot 88$ & $1 \cdot 05$ & 1.59 & $1 \cdot 24$ \\
\hline \multicolumn{4}{|c|}{ Organism: Weizmann strain. } & - & - \\
\hline
\end{tabular}

when incubated with only the glucose, butyric and acetic acid constituents of the culture produce butyl alcohol in about the normal amount. Therefore it can be said that the reduction of butyric acid is not dependent on any unknown intermediate produced during the first half of the fermentation.

Glucose as the reducing agent. The ability of glucose to function as the reducing agent of butyric acid was then examined using cell suspensions. The reaction envisaged was:

$$
\mathrm{C}_{6} \mathrm{H}_{12} \mathrm{O}_{6}+\mathrm{C}_{3} \mathrm{H}_{7} \cdot \mathrm{COOH}=2 \mathrm{CH}_{3} \cdot \mathrm{CO} \cdot \mathrm{COOH}+\mathrm{C}_{4} \mathrm{H}_{9} \cdot \mathrm{OH}+\mathrm{H}_{2} \mathrm{O} \text {. }
$$

The pyruvic acid formed would then be fermented chiefly to acetic acid (see Table 9) according to the equation:

$$
\mathrm{CH}_{3}: \mathrm{CO} \cdot \mathrm{COOH}+\mathrm{H}_{2} \mathrm{O}=\mathrm{CH}_{3} \cdot \mathrm{COOH}+\mathrm{CO}_{2}^{\circ}+\mathrm{H}_{2},
$$

the over-all reaction being:

$$
\mathrm{C}_{6} \mathrm{H}_{12} \mathrm{O}_{6}+\mathrm{C}_{3} \mathrm{H}_{7} \cdot \mathrm{COOH}+\mathrm{H}_{2} \mathrm{O}=2 \mathrm{CH}_{3} \cdot \mathrm{COOH}+2 \mathrm{CO}_{2}+2 \mathrm{H}_{2}+\mathrm{C}_{4} \mathrm{H}_{9} \cdot \mathrm{OH} \text {. }
$$

The experiment was made as set out in Table 8 . The vessel contents were analysed for acetone, butyl alcohol, acetic and butyric acids and residual glucose. It is seen from Table 8 that (1) no reduction of butyric acid by $\mathrm{H}_{2}$ alone occurs; (2) in the presence of glucose and butyrate the amount of butyl alcohol formed is greater than that produced

\section{Table 8. Reduction of butyric acid by cell suspensions in the presence of glucose}

The reactions were carried out in Krebs vessels, each containing $10 \mathrm{ml}$. cell suspension (14.5 mg. dry wt. $/ \mathrm{ml}$.) and in addition (b) contained $8 \mathrm{ml}$. $M / 2$ butyric acid adjusted to $p \mathrm{H} 5.0$ with $\mathrm{NaOH},(c) 4 \mathrm{ml}$. $M$ glucose, and $(d) 4 \mathrm{ml}$. $M$ glucose and $8 \mathrm{ml}$. M/2 butyrate $p H 5 \cdot 0$. The total volume was made up to $40 \mathrm{ml}$. with distilled water in each case. All vessels were gassed with $\mathrm{H}_{2}$ and incubated for $18 \mathrm{hr}$. at $38^{\circ}$.

(a)

Conc. $\mathrm{mg} \cdot / \mathrm{ml}$.

Initial glucose

Initial butyric acid

Glucose fermented

Butyl alcohol

Acetic acid

Butyric acid

No
substrate
None
None
None
$0 \cdot 36$
$0 \cdot 09$
$0 \cdot 13$

(b)
Butyrate
None
$8 \cdot 8$
None
$0 \cdot 28$
None
8.65

(c)

Glucose

18.5

None

$16 \cdot 3$

$3 \cdot 61$

$0 \cdot 88$

0.83 (d)

Glucose +

butyrate

18.5

$8 \cdot 8$

10.93

$4 \cdot 18$

3.72

$5 \cdot 13$ 
by the fermentation of glucose alone. The glucose fermented in this experiment (10:93 mg.) would, by itself, have produced $2.18 \mathrm{mg}$. butyl alcohol; $3.82 \mathrm{mg}$. were formed whilst $3.52 \mathrm{mg}$. butyric acid disappeared. The ratio (mol. glucose fermented/mol. butyl alcohol formed) is 2.06 for glucose alone and 1.18 for glucose + butyrate; equation (3) predicts a ratio of $1 \cdot 0$. The relationship between glucose and butyric acid disappearing and butyl alcohol and acetic acid formed is not quantitative, this would hardly be expected in such a complex system, but the evidence seems fairly good that glucose or some substance closely related to it is the reducing agent for butyric acid. Results which parallel these have been reported by Osburn, Brown \& Werkman [1938] for the fermentation of glucose in the presence of butyric acid by growing cultures of Cl. butylicum.

The same relationships between glucose and butyric acid disappearing and butyl alcohol and acetic acid formed would hold if the active reducing agent was pyruvic acid and not glucose, assuming that glucose first breaks down to pyruvic acid. The equation for the reduction would be:

$$
\mathrm{C}_{3} \mathrm{H}_{7} \cdot \mathrm{COOH}+2 \mathrm{CH}_{3} \cdot \mathrm{COCOOH}+\mathrm{H}_{2} \mathrm{O}=2 \mathrm{CH}_{3} \cdot \mathrm{COOH}+2 \mathrm{CO}_{2}+\mathrm{C}_{4} \mathrm{H}_{9} \cdot \mathrm{OH} \text {. }
$$

In this connexion it may be noted that Brown, Osburn \& Werkman [1937] have shown that suspensions of $\mathrm{Cl}$. butylicum can bring about the reduction of butyric acid in the presence of pyruvate at $p \mathrm{H} \mathrm{4.8}$ but not at $p \mathrm{H} \mathrm{6.6}$. $A$ priori evidence against this mechanism for $C l$. acetobutylicum fermentations is afforded by the nature of the reaction products when $(a)$ glucose, $(b)$ pyruvate are fermented by ripe cell suspensions. Pyruvic acid gives rise chiefly to acetic acid with some acetone and butyric acid but scarcely any butyl alcohol (Table 9). To decide whether pyruvic acid could function as the reducing agent for butyric acid an experiment was carried out in which glucose and pyruvate were fermented $(a)$ alone, $(b)$ in the presence of butyric acid. The results are given in Table 10.

Table 9. Products of fermentation of glucose and pyruvate by suspensions of ripe cells

\begin{tabular}{|c|c|c|c|c|c|}
\hline Product & $\begin{array}{c}\text { Glucose } \\
\text { mol./mol. } \\
\text { glucose } \\
\text { fermented }\end{array}$ & $\begin{array}{c}\text { Pyruvate } \\
\text { mol./2 mol. } \\
\text { pyruvate } \\
\text { fermented }\end{array}$ & Product & $\begin{array}{c}\text { Glucose } \\
\text { mol./mol. } \\
\text { glucose } \\
\text { fermented }\end{array}$ & $\begin{array}{c}\text { Pyruvate } \\
\text { mol./2 mol. } \\
\text { pyruvate } \\
\text { fermented }\end{array}$ \\
\hline $\begin{array}{l}\mathrm{CO}_{2} \\
\mathrm{H}_{2} \\
\text { Butyl alcohol } \\
\text { Ethyl alcohol }\end{array}$ & $\begin{array}{l}2 \cdot 46 \\
1 \cdot 87 \\
0 \cdot 615 \\
0 \cdot 006\end{array}$ & $\begin{array}{l}2 \cdot 077 \\
1 \cdot 87 \\
0 \cdot 011 \\
0 \cdot 049\end{array}$ & $\begin{array}{l}\text { Acetone } \\
\text { Acetic acid } \\
\text { Butyric acid }\end{array}$ & $\begin{array}{l}0 \cdot 141 \\
0 \cdot 124 \\
0 \cdot 037\end{array}$ & $\begin{array}{l}0.077 \\
1.53 \\
0.106\end{array}$ \\
\hline
\end{tabular}

The reactions were carried out in Krebs vessels containing $10 \mathrm{ml}$. cell suspension, $10 \mathrm{ml} . M / 5$ phosphate

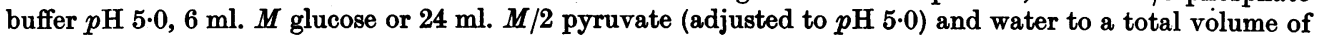
$60 \mathrm{ml}$. Gas phase $\mathrm{H}_{2}$; temp. $38^{\circ}$. Incubated for $18 \mathrm{hr}$. and then analysed. $\mathrm{CO}_{2}$ and $\mathrm{H}_{2}$ were measured in Warburg manometers using $1 / 20$ the above quantities.

Organism: BY strain.

\section{Table 10. Glucose and pyruvate as reducing agents for butyric acid}

The reactions were carried out in Krebs vessels containing $10 \mathrm{ml}$. cell suspension (16.5 mg. dry wt./ml.), $2 \mathrm{ml} . M / 2$ butyric acid (adjusted to $p H \mathrm{5} \cdot 0)$ in $(b)$ and $(d), 1 \mathrm{ml} . M$ glucose in $(c)$ and (d), 2 ml. $M$ pyruvic acid (adjusted to $p H$ 5.0) in $(a)$ and $(b)$. The volume in each case was made up to $40 \mathrm{ml}$. with water. Gas phase $\mathrm{H}_{2}$; temp. $38^{\circ}$. Incubated for $18 \mathrm{hr}$.

The products of fermentation are expressed as mol./mol. glucose fermented or mol./2 mol. pyruvate fermented.

\begin{tabular}{|c|c|c|c|c|c|c|c|c|c|}
\hline Product & $\begin{array}{c}(a) \\
\text { Pyruvate }\end{array}$ & $\begin{array}{c}(b) \\
\text { Pyru- } \\
\text { vate + } \\
\text { butyrate }\end{array}$ & $\begin{array}{c}(c) \\
\text { Glucose }\end{array}$ & $\begin{array}{c}(d) \\
\text { Glu- } \\
\text { cose }+ \\
\text { butyrate }\end{array}$ & Product & $\begin{array}{c}(a) \\
\text { Pyruvate }\end{array}$ & $\begin{array}{c}(b) \\
\text { Pyru- } \\
\text { vate + } \\
\text { butyrate }\end{array}$ & $\begin{array}{c}(c) \\
\text { Glucose }\end{array}$ & $\begin{array}{c}(d) \\
\text { Glu- } \\
\text { cose }+ \\
\text { butyrate }\end{array}$ \\
\hline $\begin{array}{l}\text { Acetone } \\
\text { Butyl alcohol }\end{array}$ & $\begin{array}{l}0.094 \\
0.048\end{array}$ & $\begin{array}{l}0.117 \\
0.046\end{array}$ & $\begin{array}{l}0 \cdot 143 \\
0.513\end{array}$ & $\begin{array}{l}0.129 \\
0.749\end{array}$ & $\begin{array}{l}\text { Butyric acid } \\
\text { Acetic acid }\end{array}$ & $\begin{array}{l}0.233 \\
1 \cdot 67\end{array}$ & $\begin{array}{l}+0.135^{*} \\
1.57\end{array}$ & $\begin{array}{l}0 \cdot 161 \\
0 \cdot 392\end{array}$ & $\begin{array}{c}-0.333 \dagger \\
0.645\end{array}$ \\
\hline
\end{tabular}

* 0.135 mol. butyric acid have been formed per mol. pyruvate fermented.

$+\mathbf{0 . 3 3 3}$ mol. butyric acid have disappeared per mol. glucose fermented.

Organism: Weizmann strain. 
It is seen that butyric acid is not reduced by pyruvate; in fact it appears to have no appreciable effect on the course of pyruvate fermentation. With glucose the results are similar to those already given in Table 8. On the basis of these results it may be suggested as a working hypothesis that triosephosphate functions as the reducing agent for butyric acid in the same way as it does for acetaldehyde in alcoholic fermentation by yeast. Attempts to isolate phosphoglyceric acid by fermenting glucose in the presence of butyrate and NaF according to the method of Stone \& Werkman [1937] have so far been unsuccessful; possibly the correct conditions have not yet been found. Neither has it been possible to ferment hexosediphosphate with or without adenylic acid as phosphate acceptor, nor to bring about the reduction of butyric acid by hexosediphosphate. These last results are, however, of no great significance as hexosediphosphate does not easily penetrate the cell wall and is, for example, not readily attacked by intact yeast cells.

\section{Intermediates in acetone production}

Early experiments have shown that acetone production by the growing organism is increased by an autolysate of liver or maize [Davies \& Stephenson, 1941]. In an attempt to concentrate the active substance precipitation by basic lead acetate was used and the filtrate, after removal of the excess $\mathrm{Pb}$ by $\mathrm{CO}_{2}$, gave with glucose a much increased acetone production when incubated with cell suspensions in the usual way. This was finally attributed to the acetic acid which remained after removal of the excess $\mathrm{Pb}$ (Table 11). The effect of acetic acid on acetone production from pyruvate was then

\section{Table 11. Effect of acetic acid on acetone production}

The reactions were carried out in Krebs vessels each containing 1 ml. $M$ glucose, $7 \mathrm{ml}$. cell suspension (12 mg. dry wt./ml.), 4.2 ml. $2 M$ acetate buffer $p H$ 5.0 in (b), 4.2 ml. liver preparation $2^{*} \cdot$ in (c), 4.2 ml. liver preparation 2 and $4 \cdot 2 \mathrm{ml} .2 M$ acetate in $(d), 4 \cdot 2 \mathrm{ml}$. lead-free filtrate as described in the text in $(e)$, and 4.2 $\mathrm{ml}$. tryptic digest of liver containing the equivalent of $1 \mathrm{mg}$. fresh liver per ml. and $4.2 \mathrm{ml} .2 M$ acetate in $(f)$. The total volume in each vessel was made up to $21 \mathrm{ml}$. with water. Gas phase $\mathrm{H}_{2} ;$ temp. $38^{\circ}$. Incubated for $18 \mathrm{hr}$.

\section{Addenda}

(a) No factor; no acetate

(b) No factor; acetic acid $24 \mathrm{mg} . / \mathrm{ml}$.

(c) $20 \%$ liver preparation 2 ; no acetate (d) $20 \%$ liver preparation 2; acetic acid

(e) $20 \%$ lead-free filtrate; no acetate

(f) $20 \%$ tryptic digest of liver and acetic acid $24 \mathrm{mg} . / \mathrm{ml}$.

$\begin{array}{ccc}\begin{array}{c}\text { Glucose } \\ \text { fermented } \\ \text { mg./ml. }\end{array} & \begin{array}{c}\text { Acetone } \\ \text { formed } \\ \text { mg./ml. }\end{array} & \begin{array}{c}\text { Acetone as } \\ \text { \% glucose } \\ \text { fermented }\end{array} \\ 9 \cdot 0 & 0 \cdot 33 & 3 \cdot 7 \\ 9 \cdot 16 & 1 \cdot 57 & 17 \cdot 2 \\ 9 \cdot 88 & 0 \cdot 34 & 3 \cdot 4 \\ 9 \cdot 85 & 1 \cdot 74 & 17 \cdot 7 \\ & & \\ 10 \cdot 16 & 1 \cdot 63 & 16 \cdot 1 \\ 10 \cdot 00 & 1.92 & 19 \cdot 2\end{array}$

* Liver preparation 2. The lead-free filtrate described in the text was acidified to $p \mathrm{H} 2$ with $\mathrm{H}_{2} \mathrm{SO}_{4}$ and the volatile acids removed by three distillations with water in vacuo; the $\mathrm{H}_{2} \mathrm{SO}_{4}$ was removed quantitatively with $\mathrm{Ba}(\mathrm{OH})_{2}$ and the fluid concentrated in vacuo so that $1 \mathrm{ml} .=1 \mathrm{~g}$. liver.

Organism: Weizmann strain.

examined together with the corresponding effect of butyrate; blanks with acetate and butyrate alone were also carried out. The results (Fig. 5) show that here too the presence of acetate resulted in a large increase in acetone formation from pyruvate; butyrate was ineffective and there was no formation of acetone from acetic or butyric acids either alone or together. With similar concentrations of acetic acid $(24 \mathrm{mg} . / \mathrm{ml}$.) the increase in acetone in both cases was about 4-5 fold. Pyruvic acid can often be demonstrated by the Simon test in cultures grown on glucose and it is probably an early intermediate in glucose fermentation [cf. Brown et al. 1937]. Attention was therefore directed to the further examination of the reaction between pyruvate and acetate.

The effect of acetate concentration on acetone production from pyruvate by cell suspensions is shown in Fig. 6 together with the corresponding curves for glucose. It is 


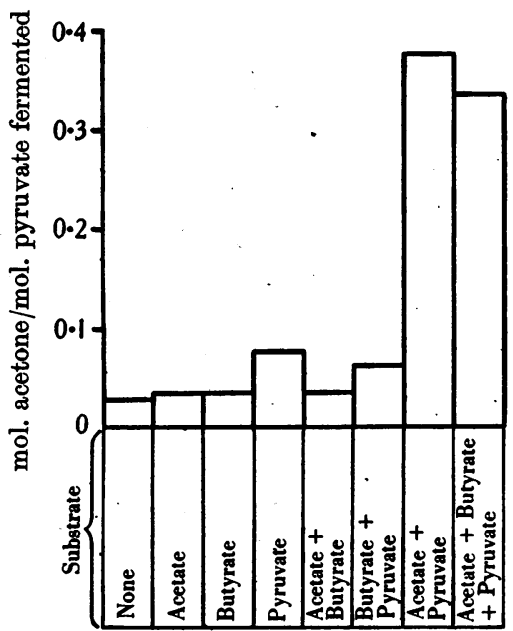

Fig. 5. Effect of acetate and butyrate on acetone production from pyruvate. The reactions were carried out in Krebs vessels containing $7 \mathrm{ml}$. cell suspension $(20 \mathrm{mg} . / \mathrm{ml}$.), $0.7 \mathrm{ml} .0 .7 M$ pyruvic acid, and where required $4.2 \mathrm{ml}$. $2 M$ acetate buffer $p H 5.0$ and/or $4.2 \mathrm{ml}$. $M / 2$ butyric acid $p H$ H.0; the total volume was made up to $21 \mathrm{ml}$. with water. Gas phase $\mathrm{H}_{2}$; temp. $37^{\circ}$. Incubated for $18 \mathrm{hr}$. and then analysed for acetone. Organism: Weizmann strain.

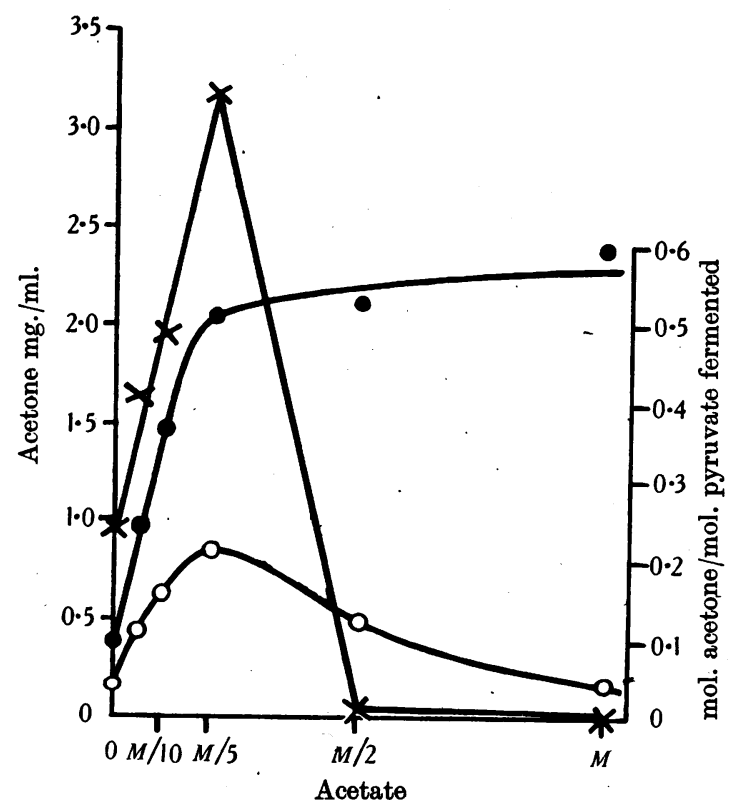

Fig. 6.

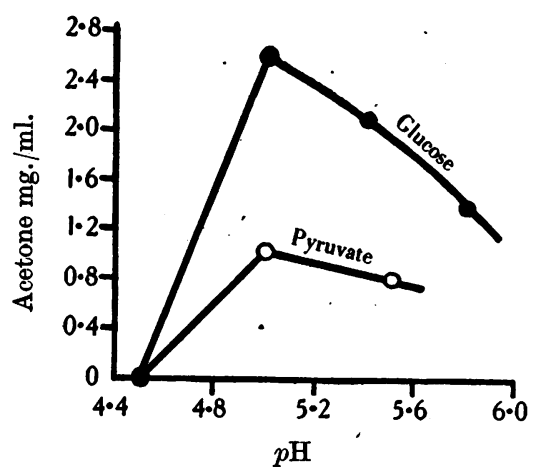

Fig. 7.

- Fig. 6. Effect of acetate concentration on acetone production. The reactions were carried out in Krebs vessels containing $2 \mathrm{ml}$. $M$ glucose or $1 \mathrm{ml} .0 \cdot 6 M$ pyruvic acid, $5 \mathrm{ml}$. cell suspension (15 mg. dry wt./ml.), and sufficient $2 M$ acetate buffer $p H$ 5.0 to give final acetate concentrations of nil, $M / 20$, $M / 10, M / 5, M / 2$, and $M$; the total volume was made up to $20 \mathrm{ml}$. with water. Gas phase $\mathrm{H}_{2} ;$ temp. $38^{\circ}$. Incubated for $18 \mathrm{hr}$. and then analysed for acetone. Organism: Weizmann strain. 0.0 Pyruvate as substrate (acetone $\mathrm{mg} . / \mathrm{ml}$ ). $\longrightarrow$ Pyruvate as substrate (acetone mols./mol. pyruvate fermented). $x-x$ Glucose as substrate (acetone $\mathrm{mg} . / \mathrm{ml}$.).

Fig. 7. Effect of $p H$ on acetone production in the presence of $M / 5$ acetate. The conditions were the same as under Fig. 6 except that all vessels contained $2 \mathrm{ml} .2 M$ acetate buffer of the desired $p$ H. Organism: Weizmann strain. 
seen that the maximum formation of acetone from both substrates occurs with a final acetate concentration of $M / 5$ and that the ratio mol. acetone $/ \mathrm{mol}$. pyruvate fermented attains a maximum steady value of about $0 \cdot 5-0 \cdot 6$. The optimum $p \mathrm{H}$ for acetone formation in the presence of $M / 5$ acetate was then determined by incubating cell suspensions with glucose or pyruvate as substrate in the presence of $M / 5$ acetate buffer of the required $p H$. Fig. 7 shows that the optimum production of acetone occurs at $p \mathbf{H} \mathbf{5 \cdot 0}$.

Role of acetic acid in acetone production. There are a number of references in the literature to the fact that the addition of acetic acid to a maize-meal or a glucose fermentation by $\mathrm{Cl}$. acetobutylicum gives rise to increased amounts of acetone [Reilly, Hickinbottom, Henley \& Thaysen, 1920; Speakman, 1920] and the hypothesis that acetone is formed from acetic acid via acetoacetic acid has been accepted by most workers [Reilly et al. 1920; Bernhauer \& Kurschner, 1935; Osburn et al. 1938; Donker, 1926; van der Lek, 1930]. It has been shown that acetoacetic acid is almost certainly the immediate precursor of acetone. If the acetoacetic acid arises from condensation of two molecules of acetic acid, as previous workers have suggested, then the condensation reaction must be one of two coupled reactions for, as is seen from Fig. 5, acetic acid alone gives rise to no appreciable amounts of acetone when incubated with cell suspensions. If pyruvic acid or glucose is present as well, then large amounts of acetone are formed. The concentration of acetic acid necessary to produce these large amounts of acetone is very high and the relationship between acetate concentration and acetone production rather suggested that the acetic acid was functioning, not by taking part in a coupled reaction, but rather by exerting a mass action effect, suppressing a particular line of breakdown of glucose or pyruvic acid and/or increasing the reaction which gives rise to acetoacetic acid. This idea agrees well with a theory of acetone formation based on the scheme of Krebs \& Johnson [1937] and indicated in the following equations [see Kalckar, 1941]:

$$
\begin{aligned}
& \mathrm{CH}_{3} \cdot \mathrm{CO} \cdot \mathrm{COOH}+\mathrm{CH}_{3} \cdot \mathrm{COOH}=\mathrm{CH}_{3} \cdot \mathrm{CO} \cdot \mathrm{CH}_{2} \cdot \mathrm{CO} \cdot \mathrm{COOH}+\mathrm{H}_{2} \mathrm{O}, \\
& \mathrm{CH}_{3} \cdot \mathrm{CO} \cdot \mathrm{CH}_{2} \cdot \mathrm{CO} \cdot \mathrm{COOH}+\mathrm{H}_{2} \mathrm{O}=\mathrm{CH}_{3} \cdot \mathrm{CO} \cdot \mathrm{CH}_{2} \cdot \mathrm{COOH}+\mathrm{CO}_{2}+\mathrm{H}_{2} .
\end{aligned}
$$

Acetopyruvic acid as an intermediate in acetone formation. Acetopyruvic acid was prepared from sodium ethyl acetopyruvate [Claisen \& Stylos, 1887] by the method of Mumm \& Bergell [1912], and its ability to function as an intermediate in the formation of acetone was examined by incubating a solution with a cell suspension and measuring gas production and acetone formation. Details are given in Table 12. From this experi-

\title{
Table 12. Attempt to ferment acetopyruvic acid
}

\begin{abstract}
Warburg manometer vessels contained $1 \mathrm{ml}$. M/5 phthalate-phosphate* buffer $p H 5.0$ or $0.3 \mathrm{ml} .2 M$ acetate buffer $p \mathrm{H} 5 \cdot 0,1 \mathrm{ml}$. cell suspension in the main compartment; $0.1 \mathrm{ml}$. $M$ acetopyruvic acid (adjusted to $p \mathrm{H} \mathrm{5 \cdot 0)}$ and/or $0 \cdot 1 \mathrm{ml}$. $0 \cdot 64 M$ pyruvic acid $(p \mathrm{H} \mathrm{4.5)}$ in the side bulb. The total volume was made up to $3.0 \mathrm{ml}$. with water. Gas phase $\mathrm{H}_{2}$; temp. $37^{\circ}$.

The acetone experiments were carried out in Krebs vessels containing $7 \mathrm{ml}$. cell suspension, $7 \mathrm{ml}$. phthalatephosphate buffer and $0.7 \mathrm{ml}$. 0.64 $M$ pyruvic acid in $(c), 7 \mathrm{ml}$. phthalate-phosphate buffer and $0.7 \mathrm{ml} . M$ acetopyruvic acid in $(a)$ and $(b), 2 \cdot 1 \mathrm{ml} .2 M$ acetate buffer and $0.7 \mathrm{ml}$. $M$ acetopyruvic acid in $(d), 2 \cdot 1 \mathrm{ml}$. $2 M$ acetate buffer and $0.7 \mathrm{ml} .0 .64 M$ pyruvic acid in $(e)$. The total volume was made up to $21 \mathrm{ml}$. with water in each case. Gas phase $\mathrm{H}_{2}$; temp. $38^{\circ}$.

Acetopyruvic acid at $p \mathrm{H} 5 \cdot 0$ did not interfere with the acetone estimations.
\end{abstract}

Organism: Weizmann strain.

Substrate

(a) Acetopyruvic acid (boiled cells)

(b) Acetopyruvic acid (phthalate-phosphate buffer)

(c) Pyruvic acid (phthalate-phosphate buffer)

(d) Acetopyruvic acid (acetate buffer)

(e) Pyruvic acid (acetate buffer)

( $f$ ) Acetopyruvic acid and pyruvic acid (phthalate-phosphate buffer)

* $M / 5$ phthalate buffer containing $10 \% M / 5 \mathrm{KH}_{2} \mathrm{PO}_{4}, p \mathrm{H}$ finally adjusted to 5.0 .
Acetone $\mathrm{mg} \cdot / \mathrm{ml}$. 0.038

0.057

$0 \cdot 117$

$0 \cdot 084$

0.597

Not done 
ment it is seen that (1) acetopyruvic acid is not attacked under the conditions used; (2) acetopyruvic acid inhibits the fermentation of pyruvic acid by about $60 \%$ at the concentration used ( $M / 30$ acetopyruvic and $M / 50$ pyruvic). There still remained the possibility that acetopyruvic acid was toxic in concentrations as high as $M / 30$; the manometric experiments were therefore repeated using $M / 300$ and $M / 3000$ acetopyruvic acid but again there was no fermentation. These experiments seem to show that acetopyruvic acid is not an intermediate in the formation of acetone.

In order to find out whether acetopyruvic acid could be fermented when added to fermenting cultures the following experiments were made. $400 \mathrm{ml} .2 \%$ glucose in the usual medium were inoculated with $10 \mathrm{ml}$. of a $5 \%$ maize culture and incubated for $20 \mathrm{hr}$. by which time fermentation was proceeding vigorously; $8 \mathrm{ml}$. of $10 \%$ acetopyruvic acid adjusted to $p \mathrm{H} \mathrm{5.0}$ were then added and the incubation continued. The culture was analysed for glucose and acetone before the addition of the acetopyruvic acid and again at the end of the incubation. It was found that the addition of the acetopyruvic acid inhibited the further fermentation of the glucose and itself gave rise to no acetone (Table 13). A similar experiment was done on $5 \%$ maize mash and gave a similar result.

\section{Table 13. Effect of acetopyruvic acid on the fermentation of glucose by a growing culture of $\mathrm{Cl}$. acetobutylicum}

The acetopyruvic acid was added to the culture immediately after the removal of the $20 \mathrm{hr}$. sample.

\begin{tabular}{|c|c|c|c|c|c|c|}
\hline & Initial & $20 \mathrm{hr}$. & $110 \mathrm{hr}$. & & Initial & $20 \mathrm{hr}$. \\
\hline $\begin{array}{l}p \mathrm{H} \\
\text { Glucose } \mathrm{mg} . / \mathrm{ml} \text {. }\end{array}$ & $\begin{array}{c}6 \cdot 70 \\
22 \cdot 0\end{array}$ & $\begin{array}{l}4 \cdot 03 \\
17 \cdot 3\end{array}$ & $\begin{array}{l}3 \cdot 89 \\
16 \cdot 0\end{array}$ & Acetone mg./ml. & - & Trace \\
\hline
\end{tabular}

When the same amount of acetopyruvic acid was added to the medium before inoculation, growth could not be initiated. It is stated that compounds containing the grouping $-\mathrm{CO}-\mathrm{CH}_{2}-\mathrm{CO}$ - are unable to pass through the cell wall [Krampitz \& Werkman, 1941]; acetopyruvic acid is such a compound and this might serve to explain why it appears not to function as a precursor of acetone were it not for the fact that it inhibits growth and fermentation. This seems to be incompatible with the theory that the acid cannot diffuse through the cell wall.

From these experiments it seems unlikely that acetopyruvic acid is an intermediate in the fermentation; some phosphorylated form of the substance may however be involved. The inhibitory effects may be due to competitive inhibition of processes in which pyruvic acid itself is concerned.

The possibility of acetone formation from acetic acid through direct condensation to acetoacetic acid was now further examined. Because no acetone is formed from acetic acid alone, whereas it is formed in increased amounts when acetic acid or glucose is also present, it must be assumed that the condensation of acetic acid to give acetoacetic acid requires energy which can be supplied by glucose or by pyruvate. On this theory the increased acetone formation from glucose or pyruvate and acetate should be accompanied by a disappearance of acetate. Accordingly, fermentations of glucose and of pyruvate in the presence of $M / 5$ acetate $p H 5 \cdot 0$ by cell suspensions were carried out and full analyses made of the products of fermentation. The results (Table 14) show that there has been a utilization of acetic acid in both cases, but the utilization is greater with glucose and acetate than with pyruvate and acetate. With glucose and acetate there has also been a considerable increase in the formation of butyric acid.

The figures in Table 14 show that about $0.5 \mathrm{~mol}$. of acetone is formed for every mol. pyruvic acid fermented in the presence of $M / 5$ acetate at $p H \mathbf{5} \cdot 0$. It follows that if the acetone has arisen from acetoacetic acid produced according to equation (7)

$$
2 \mathrm{CH}_{3} \cdot \mathrm{COOH}=\mathrm{CH}_{3} \cdot \mathrm{CO} \cdot \mathrm{CH}_{2} \cdot \mathrm{COOH}+\mathrm{H}_{2} \mathrm{O} \text {, }
$$




\section{Table 14. Effect of $\mathrm{M} / 5$ acetate on products of fermentation of glucose and pyruvate}

The reactions were carried out in Krebs vessels containing $15 \mathrm{ml}$. cell suspension, $6 \mathrm{ml} .2 M$ acetate buffer $p H 5 \cdot 0,6 \mathrm{ml}$. $M$ glucose, $11 \mathrm{ml}$. $M$ pyruvate (adjusted to $p H 5 \cdot 0$ ). The total volume was made up to $60 \mathrm{ml}$. with water. Gas phase $\mathrm{H}_{2}$; temp. $38^{\circ}$. Incubated for $18 \mathrm{hr}$. Experiments were also done with no substrate and with acetate only as substrate; the figures given below have been corrected for these blanks.

The products are expressed as mol./mol. substrate fermented.

\begin{tabular}{|c|c|c|c|c|c|c|c|c|c|}
\hline \multirow[b]{2}{*}{ Product } & \multicolumn{4}{|c|}{ Substrate } & \multicolumn{5}{|c|}{ Substrate } \\
\hline & Pyruvate & $\begin{array}{l}\text { Pyruvate } \\
\text { and } \\
\text { acetate }\end{array}$ & Glucose & $\begin{array}{l}\text { Glucose } \\
\text { and } \\
\text { acetate }\end{array}$ & Product & Pyruvate & $\begin{array}{l}\text { Pyruvate } \\
\text { and } \\
\text { acetate }\end{array}$ & Glucose & $\begin{array}{l}\text { Glucose } \\
\text { and } \\
\text { acetate }\end{array}$ \\
\hline $\begin{array}{l}\text { Acetic acid } \\
\text { Butyric acid } \\
\text { Acetone }\end{array}$ & $\begin{array}{l}0 \cdot 68 \\
0 \cdot 115 \\
0 \cdot 111\end{array}$ & $\begin{array}{c}-0 \cdot 066^{*} \\
0 \cdot 054 \\
0.473\end{array}$ & $\begin{array}{l}0 \cdot 206 \\
0 \cdot 082 \\
0 \cdot 125\end{array}$ & $\begin{array}{c}-0 \cdot 771^{*} \\
0 \cdot 280 \\
0 \cdot 491\end{array}$ & $\begin{array}{l}\text { Butyl alcohol } \\
\text { Ethyl alcohol }\end{array}$ & $\begin{array}{l}0 \\
0\end{array}$ & $\begin{array}{l}0 \\
0\end{array}$ & $\begin{array}{l}0 \cdot 547 \\
0\end{array}$ & $\begin{array}{l}0 \cdot 540 \\
0 \cdot 137\end{array}$ \\
\hline
\end{tabular}

* 0.066 and 0.771 mol. of acetic acid have been used up per mol. pyruvate and glucose fermented respectively.

Organism: Weizmann strain.

then the whole of the pyruvic acid disappearing must have been broken down to acetic acid, since the total concentration of acetate is almost unchanged. This agrees with the idea that the breakdown of pyruvic acid to acetic acid supplies the energy for the condensation of acetic acid to acetoacetic acid; it does not explain why such a high concentration of acetic acid is required to bring the acetone production up to the level of $1 \mathrm{~mol}$. per $2 \mathrm{~mol}$. pyruvate fermented. It seems that the mechanism of acetone formation still remains to be solved, but the solution must involve pyruvic and acetic acids together.

\section{Acetoacetic acid as an intermediate in butyric acid formation}

The association of an increased production of butyric acid with disappearance of acetic acid when glucose is fermented in the presence of $M / 5$ acetate suggested that acetic acid was also involved in butyric acid formation and in particular that butyric acid might be

\section{Table 15. Acetoacetic acid and butyric acid formation}

The reactions were carried out in Krebs vessels containing $12 \mathrm{ml} . M / 5$ phosphate buffer $p H 5 \cdot 65,10 \mathrm{ml}$. cell suspension (2.95 mg. dry wt. $/ \mathrm{ml}.), 2 \mathrm{ml}$. $M / 5$ glucose in $(a), 4 \mathrm{ml} . M / 10$ acetoacetic acid in $(b)$ and $2 \mathrm{ml}$. $M / 5$ glucose $+4 \mathrm{ml} . M / 10$ acetoacetic acid in $(c)$. The total volume was made up to $30 \mathrm{ml}$. with water. Gas phase $\mathrm{N}_{2}$; temp. $37^{\circ}$. Incubated for $2 \frac{1}{2} \mathrm{hr}$. A control was also done with no substrate and the figures given in the table have been corrected for this.

$\mathrm{CO}_{2}$ and $\mathrm{H}_{2}$ production were measured in Warburg manometers using 1/20 the above quantities.

\begin{tabular}{|c|c|c|c|}
\hline \multirow[b]{2}{*}{$\begin{array}{l}\text { Product } \\
\text { mg. }\end{array}$} & \multicolumn{3}{|c|}{ Substrate } \\
\hline & $\begin{array}{l}\text { Glucose } \\
\quad(a)\end{array}$ & $\begin{array}{l}\text { Acetoacetic acid } \\
(b)\end{array}$ & $\begin{array}{l}\text { Acetoacetic acid and glucose } \\
(c)\end{array}$ \\
\hline Glucose fermented & $68 \cdot 0$ & - & $68 \cdot 0$ \\
\hline & $1 \cdot 49$ & Nil & $1 \cdot 69$ \\
\hline & $29 \cdot 9$ & $2 \cdot 36$ & $\mathbf{3 6} \cdot \mathbf{5}$ \\
\hline Acetic acid & $10 \cdot 42$ & Nil & $10 \cdot 42$ \\
\hline Butyric acid & $20 \cdot 68$ & Nil & $20 \cdot 68$ \\
\hline Acetone & Nil & Not done & $8.96(3443 \mu \mathrm{l})$. \\
\hline Acetoacetic acid disappearing & - & Not done & $16 \cdot 76(3681 \mu \mathrm{l})$. \\
\hline $\mathrm{CO}_{2}$ excess in $(c)$ over $(a)$ & 一 & $一$ & $3360 \mu \mathrm{l}$ \\
\hline
\end{tabular}

formed by the reduction of acetoacetic acid. This idea was tested in the following way. A cell suspension was prepared using the cells from a young culture $(6 \mathrm{hr}$.); these cells are capable of decarboxylating acetoacetic acid at only a comparatively slow rate $\left(Q_{\mathrm{CO}_{2}}=16\right)$, but are able to form butyric acid very rapidly from glucose; they cannot form butyl alcohol or acetone. The cells were therefore in such a condition as greatly to 
favour the reduction of acetoacetic acid to butyric acid if this reaction was possible. This cell suspension was then incubated in Krebs vessels with $(a)$ glucose, $(b)$ acetoacetic acid, (c) glucose + acetoacetic acid, until fermentation ceased. The reaction mixtures were analysed for acetic and butyric acids, acetone, acetoacetic acid and residual substrate. $\mathrm{H}_{2}$ and $\mathrm{CO}_{2}$ production was measured in Warburg manometers using $1 / 20$ th the amounts of substrates in the Krebs vessels. The results (Table 15) show that acetoacetic acid has not been reduced, the whole of that disappearing being recovered as acetone.

\section{POTASSIUM AS AN ESSENTIAL FACTOR IN THE FERMENTATION OF MAIZE MEAL BY CL. ACETOBUTYLICUM (BY)}

It has been reported [Weizmann \& Davies, 1937] that if maize meal is extracted by shaking at room temperature with $0.2 \% \mathrm{HCI}$ or $\mathrm{N} / 10 \mathrm{NaHCO}_{3}$, fermentation of the resulting maize is very much slowed down although the yields of solvents are not markedly affected. The addition of fresh maize or of yeast autolysate restores the fermentation to normal.

\section{EXPERIMENTAL}

Finely ground maize meal was shaken mechanically for $2 \mathrm{hr}$. with 8 times its weight of freshly prepared $\mathrm{N} / 10 \mathrm{NaHCO}_{3}$. The larger particles were allowed to settle, the supernatant fluid was carefully decanted and centrifuged for $10 \mathrm{~min}$. at $3500 \mathrm{r} . \mathrm{p} . \mathrm{m}$. The deposit from the centrifuge was put back with the rest of the maize and the whole extraction process repeated twice more. After the third extraction the maize was suspended in about 11 . distilled water and any residual $\mathrm{NaHCO}_{3}$ neutralized with $\mathrm{N} \mathrm{HCl}$ until the $p \mathrm{H}$ was about 6.0. The maize was then filtered off on a Büchner funnel, filtriation being rapid and the filtrate water-clear, and dried at about $70^{\circ}$ for several hours. Finally it was finely ground in a small coffee grinder. Quantities of $4 \mathrm{~g}$. of this extracted maize, together with any additional substances, were made up into a mash with distilled water and diluted to $80 \mathrm{ml}$; the media were contained in long tubes $325 \times 28 \mathrm{~mm}$. Each tube was sown with $1 \mathrm{ml}$. of a $24 \mathrm{hr}$. culture of $\mathrm{Cl}$. acetobutylicum (BY) on $5 \%$ maize mash. Incubation at $37^{\circ}$ was continued until fermentation had ceased (90-100 hr.) and the cultures were then analysed for acetone and residual starch. The weight of starch fermented was obtained approximately by the following method. Aliquots of the vigorously shaken culture and of the extracted and the fresh maize were hydrolysed in 10 volumes $N \mathrm{HCl}$ at $100^{\circ}$ for $1 \mathrm{hr}$. and the liberated glucose was determined by Hanes's method [1929]. The difference between the glucose figures before and after fermentation gives the glucose equivalent of the starch fermented. The method is quick and sufficiently accurate for the purpose. In all experiments fermentations with extracted maize were compared with a fermentation of fresh maize carried out at the same time. Usually only the yield of acetone was taken as the measure of the normality of the fermentation, but in several instances butyl alcohol was also estimated and was found to confirm the acetone figures. The results (Fig. 8) have been expressed as $100 \times($ acetone produced from extracted maize)/(acetone produced from fresh maize of equal starch content).

The poor fermentability of $\mathrm{NaHCO}_{3}$-extracted maize was confirmed. The addition of $p$-aminobenzoic acid was then tried and it was found to be without effect on either the degree of fermentation or the yield of acetone. This finding was repeated five times with four different preparations of extracted maize and $p$-aminobenzoic acid concentrations from 1 to $30 \mu \mathrm{g} . / \mathrm{ml}$. Asparagine $(0 \cdot 1 \%)$, with or without $p$-aminobenzoic acid, was likewise ineffective. The extraction of the maize removes a considerable proportion of its protein and the effect of adding sufficient tryptic digest of casein to replace this was tried; 
this too was ineffective. A tryptic digest of liver was found to be very active, the yield of acetone being restored to normal by the addition of $0.5 \%$ of liver. $p$-Aminobenzoic acid with or without asparagine did not increase the effect of suboptimal amounts of liver. Wheat bran was also very efficient, $1 \%$ being even more effective than $1 \%$ liver in that with bran the fermentation was just as rapid as that of fresh maize, whereas with liver it was definitely slower although the final acetone yields were normal in both cases (see Table 17). The effect of biotin methyl ester was next examined, this substance being the only known essential growth factor for this organism not yet tried. In case a multiplicity of factors was involved the biotin was tested at a level of $0.0004 \mu \mathrm{g} . / \mathrm{ml}$. in the presence of asparagine $(0 \cdot 1 \%), p$-aminobenzoic acid $(1 \mu \mathrm{g} . / \mathrm{ml}$.) and Speakman's salts. A control

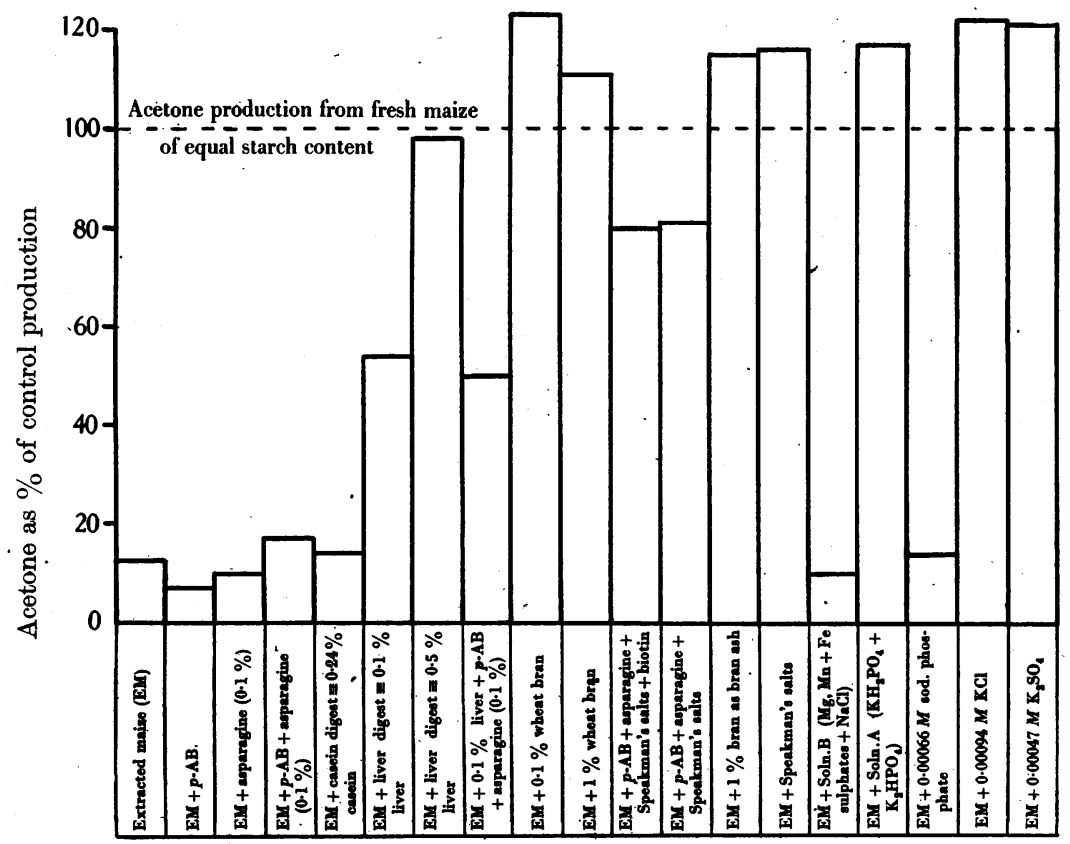

$p$ - $\mathrm{AB}=p$-aminobenzoic acid, $1 \mu \mathrm{g} . / \mathrm{ml}$.

Fig. 8. Effect of various substances on the fermentation of $\mathrm{NaHCO}_{3}$-extracted maize. For the composition of Speakman's salt mixture, see McDaniel, Woolley \& Peterson [1939]. Solution B consisted of the Mg, $\mathrm{Mn}$ and $\mathrm{Fe}$ sulphates and the $\mathrm{NaCl}$ constituents of Speakman's salts. Solution A consisted of the $\mathrm{K}_{2} \mathrm{HPO}_{4}$ and the $\mathrm{KH}_{2} \mathrm{PO}_{4}$ constituents of Speakman's salts, giving a final [K] in the medium of $0.0094 M$ and a final $\left[\mathrm{PO}_{4}\right]$ of $0.0066 M$. Organism: $\mathrm{BY}$ strain.

was done omitting the biotin. Surprisingly, the control showed a much improved fermentation and the addition of biotin gave no further improvement. Since asparagine and $p$-aminobenzoic acid together had already been shown to be without effect it was concluded that $(a)$ the improved fermentation was due to Speakman's salts, (b) biotin was not involved. Confirmation that the failure of extracted maize to ferment is due to a lack of certain salts was obtained by adding to the extracted maize ashed bran equivalent to $1 \%$ bran, when fermentation was restored to normal in so far as the yield of acetone was concerned. It was still somewhat slower than that of fresh maize. The components of Speakman's salt mixture were next tested and the whole effect was found to reside in the potassium phosphate fraction and specifically in the potassium ion, sodium phosphate being completely inactive and both $\mathrm{KCl}$ and $\mathrm{K}_{2} \mathrm{SO}_{4}$ fully active. Finally, $\mathrm{K}$ estimations were made on samples of fresh and extracted maize and the results are shown in Table 16. Extraction of the maize had reduced the $K$ content to less than $1 / 100$ th of the amount in 


\section{Table 16. Analysis of fresh and extracted maize}

Aliquots of maize were dry-ashed in a muffle furnace and the residue taken up in $2 N \mathrm{HCl}$. Potassium was estimated in the resulting solution by the method of Kramer \& Tisdall [1921].

\begin{tabular}{|c|c|c|c|c|c|}
\hline & $\begin{array}{c}\mathrm{K} \text { content } \\
\text { of maize } \\
\%\end{array}$ & $\begin{array}{c}\text { Concentration } \\
\text { of } \mathrm{K} \text { in } \\
\text { a } 5 \% \text { mash } \\
M\end{array}$ & , & $\begin{array}{c}\text { K content } \\
\text { of maize } \\
\%\end{array}$ & $\begin{array}{c}\text { Concentration } \\
\text { of } \mathrm{K} \text { in } \\
\text { a } 5 \% \text { mash } \\
M\end{array}$ \\
\hline Fresh maize & $1 \cdot 113$ & 0.0143 & Extracted maize & 0.0082 & 0.0001 \\
\hline
\end{tabular}

fresh maize and the concentration in a $5 \%$ mash of extracted maize to $0.0001 M$. When this concentration was increased to $0.001 M$ by the addition of $\mathrm{KCl}$ or $\mathrm{K}_{2} \mathrm{SO}_{4}$ the maize was fermented with a normal yield of acetone.

Visual observation showed that initially some fermentation of the extracted maize does take place and it appears to be just as rapid as that of fresh maize, but it soon comes to a standstill. This suggests that the residual $\mathrm{K}$ in the maize permits of some fermentation and that the cells take up $K$ during growth. When all the available $K$ has been exhausted growth and fermentation cease. Although the final yield of acetone can be restored to normal by $K$ salts the speed of fermentation of extracted maize in the presence of $K$ salts is still appreciably slower than that of fresh maize; $1 \%$ bran will restore both the speed and the solvent yield (Table 17). This suggests that besides $K$ there is yet another factor

Table 17. Rate of fermentation of extracted maize

1. Fresh maize

2. Extracted maize (E.M.)

3. E.M. and $1 \%$ liver digest

4. E.M. and $0.5 \%$ wheat bran

5. ..M. and $1 \%$ wheat bran

6. E.M. and Speakman's salts

7. E.M. and Speakman's salts, $p$-AB, asparagine and biotin

8. E.M. and $0.0066 M \mathrm{~K}$ phosphate

9. E.M. and $0.0094 M \mathrm{KCl}$

\begin{tabular}{|c|c|c|c|}
\hline \multicolumn{4}{|c|}{ Analyses } \\
\hline \multicolumn{2}{|c|}{$40 \mathrm{hr}}$. & \multicolumn{2}{|c|}{$112 \mathrm{hr}}$. \\
\hline $\begin{array}{c}\text { Acetone } \\
\text { mg. }\end{array}$ & $\begin{array}{c}\text { Starch } \\
\text { fermented } \\
\text { g. }\end{array}$ & $\begin{array}{c}\text { Acetone } \\
\text { mg. }\end{array}$ & $\begin{array}{c}\text { Starch } \\
\text { fermented } \\
\text { g. }\end{array}$ \\
\hline 204 & $2 \cdot 46$ & 225 & $2: 66$ \\
\hline 3 & 0.23 & 17 & 0.35 \\
\hline 90 & $1 \cdot 30$ & 209 & $2 \cdot 36$ \\
\hline 153 & 1.61 & 200 & $2 \cdot 79$ \\
\hline 240 & $2 \cdot 49$ & 261 & 2.99 \\
\hline 100 & $1 \cdot 45$ & 236 & $2 \cdot 67$ \\
\hline 87 & 0.95 & 110 & 1.51 \\
\hline 93 & $1 \cdot 29$ & 278 & $2 \cdot 63$ \\
\hline 98 & $\mathbf{1} \cdot \mathbf{3 4}$ & 280 & $2 \cdot 76$ \\
\hline
\end{tabular}

Organism: BY strain.

which is present in suboptimal amounts in extracted maize. This has not been further investigated but it is evidently not asparagine, $p$-aminobenzoic acid, or biotin, or any combination of these.

\section{Summary of Parts 2 and 3}

1. Factors affecting the rate of decay of activity of suspensions of $\mathrm{Cl}$. acetobutylicum have been investigated; the cells maintain their activity only so long as they are fermenting glucose.

2. The fermentation of maltose and sucrose by cell suspensions has been shown to be dependent on the presence of these sugars in the growth medium. The cells are capable of fermenting glucose irrespective of whether they are grown on glucose, maltose or sucrose.

3. Glyceraldehyde, phosphoglyceric acid, hexosediphosphate, lactic acid, formic acid, methylglyoxal, acetoacetic acid, oxaloacetic acid, fumaric acid, butyric acid, $\alpha$-hydroxybutyric acid, $\beta$-hydroxybutyric acid, 2:3-dihydroxybutyric acid, glyoxylic acid, tetronic acid, crotonic acid, trans- $\gamma$-hydroxycrotonic acid, tetrolic acid and vinylacetic acid have, 
been examined as possible intermediates in the fermentation of glucose. Of these only acetoacetic acid and oxaloacetic acid are attacked with the production of $\mathrm{CO}_{2}$ and/or $\mathrm{H}_{2}$.

4. None of the above compounds can be reduced by $\mathrm{H}_{2}$ in the presence of cell suspensions able to ferment glucose.

5. Acetoacetic acid is rapidly decarboxylated to acetone by suspensions of ripe cells; with young cells the decarboxylation is slow.

6. Vinylacetic, tetrolic, trans- $\gamma$-hydroxycrotonic, crotonic and fumaric acids are not appreciably attacked by cells which are actively fermenting glucose. It is therefore concluded that they are not intermediates in the fermentation of glucose.

7. Acetoacetic acid is not reduced by cells which are actively fermenting glucose under conditions where its decarboxylation is slow; therefore it is probably not the precursor of butyric acid.

8. Butyric acid is reduced to butyl alcohol by cell suspensions in the presence of glucose but not in the presence of pyruvate. It is concluded that glucose or some closely related substance, possibly triosephosphate, is the reducing agent for butyric acid.

9. The formation of acetone from glucose and from pyruvate by cell suspensions is increased 4-5 fold by the presence of $M / 5$ acetate at $p \mathrm{H} 5.0$; acetic acid alone does not give rise to acetone.

10. The increased acetone is accompanied by a utilization of acetic acid in both cases but this is greater with glucose than with pyruvate.

11. Acetopyruvic acid is not attacked by cell suspensions and is inhibitory to the fermentation of glucose, maize meal and pyruvate.

12. Potassium has been shown to be an essential factor in the fermentation of maize meal by $\mathrm{Cl}$. acetobutylicum. It is probably necessary for the growth of the organism.

I wish to express my sincere thanks to Dr M. Stephenson for a great deal of valuable advice and encouragement throughout the course of this work; to Prof. Friedmann for his expert guidance in the preparation of acetopyruvic acid; to Dr E. Watchorn for her kindness in carrying out the potassium estimations on maize meal; to Dr H. A. Krebs and Dr A. Kleinzeller for very kindly supplying me with a number of the substances examined in the course of this work; to Dr C. Weizmann for his co-operation and for his kindness in supplying me with the BY strain of $\mathrm{Cl}$. acetobutylicum. I also wish to express my gratitude to the Medical Research Council for a full time grant.

\section{REFERENCES}

Bernhauer, K. \& Kurschner, K. [1935]. Biochem. Z. 280, 379.

Brown, R. W., Osburn, O. L. \& Werkman, C. H. [1937]. Proc. Soc. exp. Biol., N.Y., 36, 203.

Claisen, L. \& Stylos, N. [1887]. Ber. dtsch. chem. Ges. 20, 2188. See also Organic Synth. 6, 40.

Davies, R. \& Stephenson, M. [1941]. Biochem. J. 35, 1320.

Donker, H. J. L. [1926]. Thesis, Technische Hoogeschool, Delft.

Green, D. E., Needham, D. M. \& Dewan, J. G. [1937]. Biochem. J. 31, 2327.

Hanes, C. S. [1929]. Biochem. J. 23, 99.

Johnson, W. A. [1939]. Biochem. J. 33, 1046.

Johnson, M. J., Peterson, W. H. \& Fred, E. B. [1933]. J. biol. Chem. 101, 145.

Kalckar, H. M. [1941]. Chem. Rev. 28, 71 .

Kramer, B. \& Tisdall, F. F. [1921]. J. biol. Chem. 46, 339.

Krampitz, L. O. \& Werkman, C. H. [1941]. Biochem. J. 35, 595.

Krebs, H. A. \& Johnson, W. A. [1937]. Biochem. J. 31, 772.

Mann, P. J. G. \& Quastel, J. H. [1941]. Nature, Lond., 147, 326.

McDaniel, L. E., Woolley, D. W. \& Peterson, W. H. [1939]. J. Bact. 37, 259.

Mumm, O. \& Bergell, C. [1912]. Ber. dtsch. chem. Ges. 45, 3040.

Osburn, O. L., Brown, R. W. \& Werkman, C. H. [1938]. Iowa St. Coll. J. Sci. 12, 278.

Reilly, J., Hickinbottom, W. J., Henley, F. R. \& Thaysen, A. C. [1920]. Biochem. J. 14, 229.

Speakman, H. B. [1920]. J. biol. Chem. 43, 401.

Stone, R. W. \& Werkman, C. H. [1937]. Biochem. J. 31, 1516.

Straub, F. B. [1939]. Biochem. J. 33, 787.

van der Lek, J. B. [1930]. Thesis, Technische Hoogeschool, Delft.

Weizmann, C. \& Davies, H. [1937]. J. Soc. chem. Ind., Lond., 56, 8T.

Woods, D. D. \& Clifton, C. E. [1937]. Biochem. J. 31, 1774. 